\begin{tabular}{|l|l|l||}
\hline \multicolumn{2}{|c|}{ PublisherInfo } \\
\hline \hline PublisherName & $:$ & BioMed Central \\
\hline \hline PublisherLocation & $:$ & London \\
\hline \hline PublisherImprintName & $:$ & BioMed Central \\
\hline \hline
\end{tabular}

\title{
Strep genomics
}

\begin{tabular}{|l|l|l||}
\hline \multicolumn{2}{|c|}{ ArticleInfo } \\
\hline \hline ArticleID & $:$ & 4438 \\
\hline \hline ArticleDOI & $:$ & $10.1186 /$ gb-spotlight-20020403-01 \\
\hline \hline ArticleCitationID & $:$ & spotlight-20020403-01 \\
\hline \hline ArticleSequenceNumber & $:$ & 104 \\
\hline \hline ArticleCategory & $:$ & Research news \\
\hline ArticleFirstPage & $:$ & 1 \\
\hline \hline ArticleLastPage & $:$ & 2 \\
\hline \hline & & RegistrationDate : 2002-4-3 \\
\hline ArticleHistory & $:$ & OnlineDate \\
\hline \hline ArticleCopyright & $:$ & BioMed Central Ltd2002-4-3 \\
\hline \hline ArticleGrants & $:$ & \\
\hline \hline ArticleContext & $:$ & 130593311 \\
\hline \hline
\end{tabular}




\section{Jonathan B Weitzman}

Email: jonathanweitzman@hotmail.com

Group AStreptococcus(GAS) infection by serotype M18 strains causes acute rheumatic fever (ARF) and can lead to pediatric heart disease. In the April 2 Proceedings of the National Academy of Sciences, James Smoot and colleagues at the National Institute of Allergy and Infectious Diseases report the genome sequence of a GAS strain (MGAS8232) isolated from a patient with ARF (Proc Natl Acad Sci USA 2002, 99:4668-4673). They compared the $1.9 \mathrm{Mb}$ genome with a closely related strain (the M1 serotype SF370 strain) and found 178 putative genes unique to MGAS8232. Several of these encode secreted proteins that may be important for host-GAS interactions. Microarray analysis of different serotype M18 strains revealed that much of the genetic variation was due to phage or phage-like sequence elements. Comparative GAS genomics should lead to greater understanding of ARF pathogenesis and potential therapeutic strategies.

\section{References}

1. Pathogenesis of group A streptococcal infections.

2. Proceedings of the National Academy of Sciences, [http://www.pnas.org]

3. National Institute of Allergy and Infectious Diseases, [http://www.niaid.nih.gov]

4. Complete genome sequence of an M1 strain of Streptococcus pyogenes. 